\title{
Pharmacognostic Characterization and Phytochemical Screening of Achyranthes Aspera Linn
}

\author{
D.A. DHALE* and SONAL BHOI \\ Department of Botany, SSVPS's, L.K.Dr.P.R.Ghogrey Science College, Dhule - 424 005, India.
}

(Received: June 11, 2013; Accepted: July 27, 2013)

\begin{abstract}
Achyranthes aspera Linn. is a well-known plant drug in Ayurvedic, Unani-Tibbi, Siddha, Allopathic, Homeopathic, Naturopathic \& Home Remedies. The present communication deals with the pharmacognostic evaluation on the different parts of Achyranthes aspera Linn. (Amaranthaceae). Macroscopic and microscopic examinations of the different organ, observations and differential microchemical test has been carried out for the authentication of the samples. Physiochemical values such as the moisture contents, percentage of total ash, acid insoluble ash, acid soluble ash, extractive values like petroleum ether-soluble extractives, ethanol-soluble extractives, methanol-soluble extractives and water-soluble extractives were calculated as well as colour reactions of powder and extract with different chemicals were performed. The extracts were subjected to qualitative screening test for various constituents. This revealed the presence protein, glycosides, alkaloids, tannins and phenolic compound, steroid reducing sugars and saponin glycosides. These observations will help in the Pharmacognostical identification and standardization of the drug in the crude form and also to distinguish the drug from its adulteration.
\end{abstract}

Key words: Achyranthes aspera, Acanthaceae, pharmacognosy, Ayurveda, Unani-Tibbi, Homeopathy, Naturopathy.

\section{INTRODUCTION}

$\begin{array}{ll}\text { Botanical Name } & : \text { Achyranthes aspera Linn. Var. } \\ \text { Family } & : \text { Amaranthaceae } \\ \text { Sunskrit Name } & : \begin{array}{l}\text { Apamargah, Mayoorah, } \\ \text { Markatapippalee, }\end{array} \\ & \begin{array}{l}\text { Durgrahah. } \\ \text { Marathi Name }\end{array} \\ \text { Hindi Name } & \text { Aaghada. } \\ \text { English Name } & : \text { Chirchira, Latjira, Onga } \\ & \text { Prickly chaff flower. }\end{array}$

\section{Botanical Description}

Plants are small, much branched, monoecious perennial subshrub up to $0.8-1 \times 0.8$ $\mathrm{m}$. Rootstock stout, woody. Stems somewhat succulent at first, ribbed, becoming basally woody with age, denselycovered in velutinous, appressed hairs. Leaves opposite, densely clustered toward branch tips $40-50 \times 25-30 \mathrm{~mm}$, spreading to decurved, mostly broadlyovate, ovate-orbicular or elliptic; apex blunt to abruptly sub acute, sometimes very shortly apiculate; base attenuate; lamina somewhat fleshy, purple-grey, veins often purple, abaxial and adaxial surfaces silkycanescent, margins crenulate to crenate. Petioles $5-10 \mathrm{~mm}$ long, pink, fleshy, velutinous, basal abscission zone present. Inflorescence a terminal erectspike, 150$200 \mathrm{~mm}$ long; peduncle $15 \mathrm{~mm}$ long, fleshy, whitevillous; spike rachis fleshy, white-villous to purplevillous; flowers bisexual, retrorse, sessile, 180-200 per spike, these spaced initially at $10-\mathrm{mm}$ intervals along rachis, diminishing rapidly to $<1$-mm intervals toward inflorescence apex. Bract persistent on rachis, ovate to lanceolate $3-3.5 \times 0.5-1 \mathrm{~mm}$, strongly retrorse, chartaceous, weakly keelednear apex only, pale white, margins entire, apex acute, sometimes with a small, $0.1-0.2-\mathrm{mm}$-long pale yellow mucro. Bracteoles 2; abscissing with senescent flowers; broadly ovate, $0.2-1 \mathrm{~mm}$ long, 
chartaceous hyaline, lustrous, pale caramel; margins entire; strongly keeled, keel lustrous, caramel brown, extending well beyond bract as a hardened, chan-nelled, strongly recurved, falcate spine $4-5 \mathrm{~mm}$ long. Perianth segments (sepals) 5 , lanceolate, centralportion pale caramel-brown but distinctly pink-tinged, margins pale yellow or offwhite opaque, hyaline; segments sub equal, 4.5$6 \mathrm{~mm}$, channelled. Stamens 4 , connate at base, the filaments $0.5-1 \mathrm{~mm}$, alternating with 4 narrowly spathulate, $0.4 \times 0.6 \mathrm{~mm}$, white-hyaline, petaloid, fimbriate-argined pseudo staminodes; anthers 0.4$0.6 \mathrm{~mm}$, yellow, bilocular, dehiscing via longitudinal slits; pollen yellow. Style $0.6-1 \mathrm{~mm}$, pink to pale orange, aris-ing from a fleshy papillate style base $0.8 \mathrm{~mm}$ diam.; stigma brown, truncate. Utricle 2$2.5 \mathrm{~mm}$ long, dark brown, turbinate, chartaceous, surmounted by the dry, somewhat woody, style base. Seed 1.2-1.8 $\times 0.9-1.2 \mathrm{~mm}$, ovoid to ellipsoid, dark chestnut brown ${ }^{1}$.

\section{Medicinal Properties and uses}

Bitter, pungent, heating, laxative, stomachic, carminative, improves appetite, useful in vomiting, bronchitis, vata, heart disease, piles, itching, abdominal pains, ascites, dyspepsia, dysentery, blood disease ${ }^{2}$.

Achyranthes aspera is widely used for asthmatic cough, snakebite, hydrophobia, urinary calculi, rabies, influenza, piles, bronchitis, diarrhoea, renal dropsy, gonorrhoea and abdominal pain ${ }^{3-7}$. A powder of dried leaf mixed with honey is useful in the early stages of asthma ${ }^{8}$. One of the drugs from Siddha system of medicine, Naayuruvi kuzhi thailum has $A$. aspera as the primary constituent is reported to be quite effective in the management of asthma ${ }^{9}$.

Traditionally, the plant is used in asthma and cough. It is pungent, antiphlegmatic, antiperiodic, diuretic, purgative and laxative, useful in oedema, dropsy and piles, boils and eruptions of skin etc. Crushed plant is boiled in water and is used in pneumonia. Infusion of the root is a mild astringent in bowel complaints. The flowering spikes or seeds, ground and made into a paste with water, are used as external application for bites of poisonous snakes and reptiles, used in night blindness and cutaneous diseases ${ }^{10}$.
The plant is used in dropsy, piles, skin eruptions, colic, as diuretic, astringent and purgative ${ }^{11-13}$, as an antidote to snake bite ${ }^{14}$, in fractured bones ${ }^{15-17}$, whooping cough, respiratory troubles ${ }^{18}$, in asthma ${ }^{19}$, laxative ${ }^{4}$ and in leucoderma ${ }^{20}$. The inflorescence is used in cough ${ }^{21}$ and in hydrophobia ${ }^{17}$. Fruit is used in hydrophobia ${ }^{4}$. The seeds are employed as an emetic, purgative, and cathartic, in gonorrhoea, for insect bite and in hydrophobia $20-22$, cough including whooping cough $^{22}$, as an anti-asthmatic ${ }^{22}$. The leaves are used in wounds, injuries ${ }^{23}$, in intermittent fever, as an antiasthmatic, for urination, dog bite ${ }^{15,17}$ and in typhoid ${ }^{21}$. The root is used in whooping cough, tonsillitis ${ }^{15,17}$, Hemorrhage $^{20}$, cough and hydrophobia, as an antiasthmatic ${ }^{15}$, diuretic, diaphoretic, and antisyphilitic ${ }^{10}$.

\section{MATERIALS AND METHODS}

The fresh, healthy, mature plants were collected from farm of Dhule away from pollution. The plant materials were identified using the Flora of Dhule and Nandurbar District ${ }^{23}$, Department of Botany, SSVP Sansthas, L.K.Dr. P.R. Ghogrey Science College, Deopur, Dhule-(M.S) India and herbariums were also preserved. The leaves, stem and roots were washed and used for the present study. The macroscopic observations of the mature plants, leaves, inflorescences and other parts were noted down. For microscopic studies, some plant material preserved in $70 \%$ alcohol. Leaf epidermal studies were carried out on fresh specimens. Peels were removed mechanically using some chemicals. They were stained in $1 \%$ safranin mounted in glycerin and made semi-permanent by ringing with DPX solution. Stomatal index (SI), stomal frequency, vein-islet, vein termination number and palisade ratio were calculated as defined by Salisbury ${ }^{24,25}$.

$$
S I=\frac{S}{E+S} \times 100
$$

Where ' $S$ ' $=$ number of stomata per unit area and ' $E$ ' = number of epidermal cells in the same area. Stomatal index (SI), stomal frequency, vein-islet, vein termination number and palisade ratio have been calculated out of an average of 10 readings. 
Transections of leaf, petiole, stem and root were taken by free hand. Fresh and preserved materials were used. Sections were stained in safranin (1\%), light green (1\%) and mounted in DPX after the customary dehydration. Some hand sections were also examined in glycerine. Microphotographs of leaf, petiole, stem and root sections were taken by using DIGI- EYE High resolution Cameras affixed to microscope Olymphus $\mathrm{CH} 20$.

The fresh, healthy plants were rooted out and washed with water. They were separated as root, stem and leaves and shade dried. The dried plant materials were pulverized into fine powder using a grinder (mixer). About $1 \mathrm{~kg}$ of powdered material was prepared. After that powder were kept into air tight bags. Physiochemical values such as the percentage of total ash, acid insoluble ash, acid soluble ash, extractive values like petroleum ethersoluble extractives, etahnol-soluble extractives, methanol-soluble extractives, and watersoluble extractives were calculated according to the methods described in the Indian pharmacopoeia ${ }^{26,27 .}$

Phytochemical studies such as qualitative examination were done on the dried powdered material for this about $5 \mathrm{gm}$ of powdered material was extracted in soxhlet extraction apparatus with $250 \mathrm{ml}$ of each of the following solvents; ethanol, methanol, diethyl ether, and chloroform ${ }^{28}$. The respected solvents were evaporated (at $40^{\circ} \mathrm{C}$ ) with the help of heating mantle. Some of the extracts of each solvent were used for the qualitative phytochemical screening for the identification of the various classes of active chemical constituents, using standard prescribed methods $^{29-32}$. The positive tests were noted as present (+) and absent (-).

Physiochemical values such as the percentage of total ash, acid insoluble ash, acid soluble ash, extractive values like petroleum ethersoluble extractives, alcohol-soluble extractives and water-soluble extractives were calculated according to the methods described in the Indian pharmacopoeia ${ }^{33,34}$.

\section{RESULTS AND DISCUSSIONS}

The first step towards ensuring quality of starting material is authentication. Thus, in recent years there has been a rapid increase in the standardization of selected medicinal plants of potential therapeutic significance ${ }^{35,36}$. Despite the modern techniques, identification of plant drugs by pharmacognostic studies is more reliable. According to the World Health Organization, the macroscopic and microscopic description of a medicinal plant is the first step towards establishing the identity and the degree of purity of such materials and should be carried out before any tests are undertaken. The result of this study as follows:

\section{Macroscopic characters}

Plants are erect, woody, tall herb, leaves elliptical, ovet, elliptic lanceolate, $3-6 \times 2-3.5 \mathrm{~cm}$. membranous, acut or rounded at base silky beneath, flower pale green in terminal, Simple and branched spike reaching $30 \mathrm{~cm}$ long in fruit, utricles at apex, rounded at base, brown. The dried leaves had a characteristics odour and were slightly mucilaginous in taste.

\section{Microscopic Characters Epidermal features}

The epidermis cells are more or less straight and wavy walled with thick cuticle. The anticlinal epidermal cell walls are straight, arched or sinuous. The adaxial epidermal cells are large with thin walls as compared to the abaxial epidermal cells. The cells of lower epidermis are wavy walled single layered. Nonglandular trichomes and fglandular trichomes are observed on the surfaces but lower surface possess greater number of trichomes. The Glandular trichomes are with uni to tricellular stalk and unicellular head. The cells on the veins are generally elongated. The cells in the intercostals region are variously oriented. Stomata are present on the adaxial and abaxial surface of the leaf and are densely covered with trichomes. The shape of stomata is generally circular, oval or elliptical in outline. The stomata are anisocytic and anomocytic.

\section{T. S. of Petiole}

The petiole is crescent shaped in out line. 
Single layered epidermis composed of thin-walled cubical to oval cells covered with thick cuticle. Stomata are few. Glandular and non- glandular trichomes are common. Epidermis is followed by multilayered hypodermis of collenchyma cells. Hypodermis is followed by wide zone of thin walled parenchymatous cortex containing calcium oxalate crystals. The three vascular bundle has found situated to mid region. Phloem consists of sieve tubes, companion cells and phloem parenchyma and xylem consists of vessels trachids and xylem parenchyma.

\section{T. S. of Leaf}

The leaf is dorsiventral and hypostomatic. The lamina shows a single layered epidermis on the upper side composed of cubical cells. The upper epidermis shows mostly uni, bi and multicellular hairs. Glandular hairs are rare. The epidermis is followed by a layer of hypodermis which is usually 3-5 layers of cells thick and is interrupted at places by the palisade layer. The cells of lower epidermis are cubical in shape mostly with uni - tricellular trichomes. Three vascular bundles are scattered in ground tissue consisting of thin layered parenchymatous cells. Vascular bundle consists of xylem vessels, trachids and xylem parenchyma, Phloem consists of sieve tubes, companion cells and phloem parenchyma and pericycle. The pericycle is made of 2-3 layers of thick-walled, nonlignified cells.

\section{T. S. of Stem}

A transverse section of stem have wavy cylindrical in outline and shows the presence of both glandular and non-glandular trichomes. Single layered epidermis is covered by thick cuticle; following the epidermis is a band of collenchyma of 4-8 layers of cells. Thin walled cork cells; pericycle a discontinuous ring of lignified fibres. The cortical zone is wide with uniform width, vascular tissues show anomalous secondary

Table 1: Quantitative microscopy of the leaves of Achyranthes aspera

\begin{tabular}{llll}
\hline S. No. & Parameter & Range & Mean \\
\hline 1 & Stomatal frequency (upper surface) & $73-113$ & 93 \\
2 & Stomatal frequency (lower surface) & $162-190$ & 176 \\
3 & Stomatal index (upper surface) & $7.3-11.3$ & 9.3 \\
4 & Stomatal index (lower surface) & $16.2-19.0$ & 17.65 \\
5 & Veinislet number & $10.1-13.1$ & 11.1 \\
6 & Vein termination & $8.5-13.1$ & 10.8 \\
7 & Palisade ratio & $1.13-1.18$ & 1.16 \\
\hline
\end{tabular}

Table 2: Qualitative phytochemical of Achyranthus aspera.

\begin{tabular}{|c|c|c|c|c|c|c|c|}
\hline \multirow{2}{*}{$\begin{array}{l}\text { S. } \\
\text { No. }\end{array}$} & \multirow[t]{2}{*}{ Test } & \multicolumn{2}{|c|}{ Leaves Ex.in } & \multicolumn{2}{|c|}{ Stem Ex. in } & \multicolumn{2}{|c|}{ Root Ex. in } \\
\hline & & Enol & Mnol & Enol & Mnol & Enol & Mnol \\
\hline 1 & Protein & ++ & ++ & +++ & +++ & ++ & ++ \\
\hline 2 & Glycosides & - & - & + & + & - & - \\
\hline 3 & Alkaloids & ++ & ++ & ++ & ++ & ++ & ++ \\
\hline 4 & Tannins and Phenolic compound & ++ & ++ & ++ & ++ & ++ & ++ \\
\hline 5 & Steroid & + & + & ++ & ++ & ++ & ++ \\
\hline 6 & Saponin glycosides & ++ & + & + & + & + & + \\
\hline 7 & Reducing sugar & +++ & +++ & ++ & +++ & ++ & +++ \\
\hline
\end{tabular}

$(+++)$ appreciable amount; $(++)$ moderate amount; $(+)$ trace amount and (-) completely absent; Enol= Ethanol; Mnol=Methanol; Ext=Extract 
growth having incomplete ring of xylem and phloem; cambial strip present between secondary xylem and phloem; vessels helical, spiral and pitted. Starch grains, calcium oxalate crystals of acicular and prismatic types and cystoliths are found abundantly in the region of the stem. The central wide region is pith having oval to polygonal parenchymatous cells.

\section{T. S. root}

In sectional view it is circular. Epidermis has small cells compactly arranged. Periderm formation is noted. Cork is 3-5 layered made up of rectangular cells compactly arranged in radial rows. Below it a few layered phelloderm. Ground tissue has phloem fibres, stone cells, oxalate crystals and starch grains. Secondary growth is more. Xylem developed in large amount. Medullary rays of 1-3 rows of cells.

\section{Quantitative microscopy}

The leaf microscopic characters like stomatal frequency, stomatal index, vein islet number, vein termination and palisade ratio were determined (Table 1).

Table 3: Powder Analysis with Chemical Agents of Achyranthes aspera

\begin{tabular}{|c|c|c|c|c|}
\hline S. No. & TEST & LEAF & STEM & ROOT \\
\hline 1 & Powder & Green & Light green & White \\
\hline 2 & Pd+lodine & Dark red & Orange reddish & Dark red \\
\hline 3 & $\mathrm{Pd}+5 \% \mathrm{FeCl}_{3}$ & Light orange & Light yellow & Light orange \\
\hline 4 & $\mathrm{Pd}+1 \mathrm{~N} \mathrm{NaOH}$ & Green yellow & Light yellow & Light yellow \\
\hline 5 & $\mathrm{Pd}+$ Acetic acid & Greenish yellow & Light yellow & Whitish \\
\hline 6 & $\mathrm{Ext}+\mathrm{A} \cdot \mathrm{A} \cdot+50 \% \mathrm{H}_{2} \mathrm{SO}_{4}$ & Yellowish green & Dark yellow & Light brown \\
\hline 7 & $\mathrm{Pd}+50 \% \mathrm{H}_{2} \mathrm{SO}_{4}$ & Greenish brown & Brown & Radish brown \\
\hline 8 & $\mathrm{Pd}+50 \%$ Conc. $\mathrm{HCl}$ & Greenish yellow & Green & Feint brown \\
\hline 9 & $\mathrm{Pd}+$ Ammonia & Yellowish green. & Brownish red & Yellow \\
\hline 10 & $\mathrm{Ext}+4 \% \mathrm{NaOH}+1 \% \mathrm{CuSO}_{4}$ & Dark brown & Dirty green & Light green \\
\hline 11 & $\mathrm{Ext}+40 \% \mathrm{NaOH}+1 \%$ Lead acetate & Dark brown & Light yellow & Whitish \\
\hline 12 & $\mathrm{Pd}+50 \% \mathrm{HNO}_{3}+$ Picric acid & Greenish yellow & Green & Yellow \\
\hline 13 & Pd+Satu.Picric acid & Greenish yellow & Yellow & Greenish yellow \\
\hline
\end{tabular}

Abbreviations: $\mathrm{Pd}=$ Powder $\mathrm{A} . \mathrm{A}=\mathrm{Acitic}$ Acid, Ext=Extract

Table 4: Physical Evaluation (\% w/w)of Achyranthes aspera

\begin{tabular}{llccc}
\hline \multirow{2}{*}{ S. } & \multirow{2}{*}{ Parameter } & \multicolumn{2}{c}{ Value (\%w/w) } & \\
\cline { 3 - 5 } & & Leaves & Stem & Root \\
\hline 1. & Moisture content & 6.10 & 6.50 & 6.30 \\
2. & Extractive values & & & \\
& a) Petroleum Ether & 5.50 & 4.50 & 3.20 \\
& b) Ethanol & 7.85 & 8.50 & 7.70 \\
& c) Methanol & 6.55 & 6.70 & 6.20 \\
d) Water & 8.65 & 9.98 & 8.85 \\
& Ash values & & & \\
& a) Total ash & 14.50 & 15.45 & 15.10 \\
& b) Acid insoluble Ash & 9.40 & 9.20 & 9.10 \\
& c) Acid soluble Ash & 5.10 & 6.25 & 6.0 \\
\hline
\end{tabular}




\section{Qualitative Phytochemical screening}

The extracts and powder drug were subjected to phytochemical screening for the presences of type of phytoconstituets. The extracts and powder were found to contain protein, glycosides, alkaloids, tannins and phenolic compound, steroid reducing sugars and saponin glycosides (Table 2).

\section{Powder Drug with Chemical Reagents}

The powder drug with different chemical reagents show different colour when seen on naked eye. (Table 3)

\section{Physical constants}

Results of moisture contents, ash analysis and extractive values of the dried stem and root have been presented in Table 4 .

\section{CONCLUSION}

The present study shows the major pharmacongonstic characters in the selected parts of species $A$. aspera. The extractive values are useful to evaluate the chemical constituents present in the crude drug and also help in estimation of specific constituents soluble in a particular solvent ${ }^{37}$. In the present investigation we observed the high extractive values in ethanol compared to other solvents. The pharmacognostical characters reported in this work can serve as a valuable source of information and provide suitable diagnostic tool for the standardization as well as identification of adulterants in future investigation or application. It will also be immense using carrying out further research and revalidation of its use. The microscopic features could help in laying down micro morphological standards as per WHO guidelines for authentication of the original drug.

\section{ACKNOWLEDGEMENTS}

The author is thankful to the University Grant Commission (WRO, Pune), New Delhi for financial assistance in form of a minor project.

\section{REFERENCES}

1. Lange P. J. de, R. P. Scofield and T. Greene Achyranthes aspera(Amaranthaceae) a new indigenous additionto the flora of the Kermadec Islands group, New Zealand Journal of Botany 42: 167-173 (2004).

2. Agharkar S.P, Medicinal plants of Bombay Presidency, Scientific Publication, Jodhpur (India) (1991).

3. Jain S. P, Puri H. S. Ethnomedical plants of Janusar-Bawar hills UttarPradesh, India. J Ethnopharmacol. 12: 213-222 (1984).

4. John D. One hundred useful raw drugs of the Kani tribes of Trivendrum forest division, Kerala. India, Int J Crude Drug Res. 22: 1739 (1984).

5. Singh Y. N. Traditional medicine in Fiji, some herbal folk cures used by Fiji Indians. $J$ Ethnopharmacol., 15: 57-88 (1986).

6. Reddy M. B, Reddy K. R, Reddy M. N. A survey of plant crude drugs of Anantpur district, Andhra Pradesh, India. Int J Crude Drug Res. 27: 145-155 (1989).

7. Bhattari M. K. Medical ethno botany in the
Rapti zone, Nepal. Fitoterapia. 64: 483- 489 (1993).

8. Singh V. Traditional remedies to treat asthma in northwest and Trans Himalayan regions in J. \& K. State. Fioterapia. 56(6): 507-509 (1995).

9. Suresh A, Anandan T, Sivanandam G, Veluchamy G. A pilot study of Naayuruvi Kuzhi Thailam in Eraippunoi (bronchial asthma). J Res Ayur Siddha. 6: 171-176 (1985).

10. Nadkarni K.M. "Indian Materia Medica", 3rd edition reprinted, Bombay Popular Prakashan, 1: 21 (2009).

11. Bhatnagar L. S, Singh V. K, Pandey G. Medicobotanical studies on the flora of Ghaigaon forests, Gwalior, Madhya Pradesh. J Res Indian Med. 8: 67-100 (1973).

12. Raj K. P. S, Patel M. R. Some medicinal plants of Cambay and its immediate vicinity and their uses in Indian indigenous system of medicine. Indian Drugs. 15: 145-152 (1978).

13. Khanna K. K, Mudgal V, Shukla G, Srivastava P. K. Unreported ethno medicinal uses of 
plants as aphrodisiac from the folklores of Uttar Pradesh plains, India. Bull Bot Surv India. 36: 91-94 (1994).

14. Elvanayagum Z. E, Gnavanendham S. G, Balakrishna K, Bhima R. R, Usman S. A Survey of medicinal plants with anti snake venom activity in Chengalpattu district, Tamil Nadu, India. Fitoterapia. 66: 488-492 (1995).

15. Singh V. K, Ali Z. A. Folk medicines of Aligarh (Uttar Pradesh), India. Fitoterapia. 60: 483490 (1989).

16. Girach R. D, Aminuddin A, Khan S. A. Ethno medicinal uses of Achyranthes aspera in Orissa (India). Int J Pharmacog., 30: 113-115 (1992).

17. Anis $M$, Iqbal $M$. Medicinal plantlore of Aligarh, India. Int J Pharmacog. 32: 59-64 (1994).

18. Husain W, Siddiqui M. B. Ethno-botanical approach of North-western U.P. Acta Bot Indica. 15: 94-97 (1987).

19. Reddy M. B, Reddy K. R, Reddy M. N. A survey of medicinal plants of Chenchu tribes of Andhra Pradesh, India. Int J Crude Drug Res. 26: 189-196 (1988).

20. Pal D. C, Jain S. K, Notes on Lodha medicine in Midnapur district, W. B., India. Econ Bot. 43: 464-470 (1989).

21. Sebastnia M. K, Bhandari M. M. Medico ethno botany of Mount Abu, Rajasthan, India. J Ethnopharmacol. 12: 223-230 (1984).

22. Singh V, Pandey R. P. Medicinal plant-lore of the tribals of eastern Rajasthan (India). J Econ Tax Bot. 1: 137-147 (1980).

23. Patil D.A., Flora of Dhule and Nandurbar District, Bishen Singh Mahendrapal singh, Dehra Dun (India) (2003).

24. Salisbury, E.J. On the cases \& ecological significanc of stomatal frequency with special referances to the wood land flora Phil Trans. Roy, Soc. London, 216: 1 (1927).

25. Salisbury, E.J. The interpretation of soil climate \& the use of stomatale frequency index of water reduction to plant Beih. Bot. Zeni-ralb. 49: 408 (1932).

26. Annonymous: Indian Pharmacopoeia., 2.3 $3^{\text {rd }}$
Ed. Govt. of India, Ministry of Health, Controller of Publications, New Delhi, India (1966).

27. Annonymous: Indian Pharmacopoeia. vol. $2.3^{\text {rd }}$ Ed. Govt. of India, Ministry of Health, Controller of Publications, New Delhi, India; pp. A74 - A75 (1985).

28. Vogel Al., In: Elementary practical organic chemistry (second edition), Orient Longman Limited, 45-168.(1988).

29. Harborne JB. Phytochemical Methods, Chapman Hall, London ,pp 100-101 (1984).

30. Trease E and Evans WC., Pharmacognosy, Billiare Tindall, London (1987).

31. Ajaiyeoba EO., Phytochemical and antimicrobial studies of $G$ gynandra and $B$ coriaceae extracts. Afr. J. Biomed. Res. 3(3): 161-165 (2000).

32. Edeoga HO, Okwu DE and Mbaebie BO. Phytochemical constituents of some Nigerian medicinal Plant. African J. Biotechnology, 4(7): 685-688 (2005).

33. Annonymous. Indian Pharmacopoeia. vol. $2.3^{\text {rd }}$ Ed. Govt. of India, Ministry of Health, Controller of Publications, New Delhi, India (1966).

34. Annonymous. Indian Pharmacopoeia. vol. $2.3^{\text {rd }}$ Ed. Govt. of India, Ministry of Health, Controller of Publications, New Delhi, India. pp. A74 - A75 (1985).

35. Thomas S., Patil D.A, Patil A.G, Naresh Chandra: Pharmacognostic evaluation and physicochemical Analysis of Averrhoa carambola L. Fruit Journal of Herbal Medicine and Toxicology 2(2): 51-54 (2009).

36. Usha Kuamari J., Navas M, Mathew Dan, Rajasekharan S: Pharmacognostic studies on Acrotrema arnottianum Wight - A promising ethnomedicinal plant. Indian Journal of Traditional Knowledge 8(3): 334337 (2009).

37. Wink, M: A short history of alkaloids. In: Roberts, M.F., Wink, M. (Eds), Alkaloids: Biochemistry, Ecology and Medicinal Applications. Plenum, New York, pp. 11-44 (1998). 